\title{
Topoğrafya ve Bazı Toprak Özelliklerinin Coğrafi Bilgi Sistemleri (CBS) Ortamında Analiz Edilerek Ceviz Yetiştiriciliğine Uygun Alanların Belirlenmesi: Tekirdağ İli Merkez Köyleri Örneği
}

\author{
Lokman DELİBAȘ $^{1}$, M. Cüneyt BAĞDATLI ${ }^{* 2}$, Abdulkadir DANIŞMAN $^{1}$ \\ ${ }^{I}$ Namık Kemal Üniv., Ziraat Fak., Biyosistem Mühendisliği Bölümü, Tekirdăg \\ ${ }^{2}$ Nevşehir Hacı Bektaş Veli Üniv., Müh. Mim. Fak., Biyosistem Mühendisliği Bölümü, Nevşehir
}

Geliş tarihi/Received 20.03.2014

Düzeltilerek geliş tarihi/Received in revised form 30.12.2014

Kabul tarihi/Accepted 22.01.2015

$\ddot{O}_{z e t}$

Bu çalışma, Tekirdağ ili merkez ilçeye bağlı toplamda 55 adet köyde eğim, bakı ve toprak özellikleri ile toprak haritalarının çakıştırlması sonucunda alternatif ürün yetişstiriciliğine (ceviz) uygun alanların belirlenmesi amacıyla yürütülmüştür. Bu bağlamda Coğrafi Bilgi Sistemleri (CBS) ortaminda Arc GIS 10.1 yazıllımı kullanılarak araştırma alanina ait ve alternatif ürün yetiștiriciliğinin belirlenmesinde etkin rol oynayan eğim, bakı ve bazı toprak özellikleri belirlenmiştir. Yapılan mekansal analizler sonucunda eğim bakımından araştırma sahasında en fazla 24.934 ha alanda \%2'lik eğim grubunun hakim olduğu belirlenmiştir. Toprak derinliği bakimindan 66.154 ha ile en fazla A derinlik sinıfina sahip alanların olduğu ortaya konulmuştur. Araştırma sonucunda eğim, bakl ve bazı toprak özellikleri dikkate alınarak 11.140 ha alan ceviz yetiştiriciliğine uygun olarak belirlenmiştir.

Anahtar kelimeler: Tekirdağ, Ĕgim, Bakı, Toprak, Ceviz, CBS

\section{Determined Appropriate Area of Walnut Analyzing Properties of Some Soils Using Geographic Information Systems (GIS): The Case of Central Village Tekirdag Province}

\begin{abstract}
In this study was conducted in order to determine the appropriate area of alternative products (Walnut) in total of 55 villages of the central district of Tekirdag slope, aspect and soil maps, in matching the characteristics of the soil. In this context, Geographic Information Systems (GIS) environment using Arc GIS 10.1 software in the field of research and agricultural sustainability plays a crucial role in determining the slope, aspect, and some soil properties were determined. As a result of the research field of spatial analysis in terms of the inclination of the slope of $2 \%$ over 24.934 hectares of land were dominant group. Maximum of 66.154 hectares area in terms of the depth of 'A' soil depth and determined that all the fields of the class. In conclusion slope, soil characteristics, and taking into account some 11.140 hectares of walnut growers is determined according to.
\end{abstract}

Keywords: Tekirdag, Slope, Aspect, Soil, Walnut, GIS

\footnotetext{
*M. Cüneyt BAĞDATLI, cuneytbagdatli@gmail.com, Tel: (0545) 7990102
} 


\section{Giriş}

İnsanların yaşam koşulları ve davranışları, bulundukları çevrenin değiştirilemez topografik özellikleri ile yakından ilişkilidir. Tarım, ulaşım, iklim, eğitim, geçim kaynakları, yerleşim yerinin niteliği, gelişebilme potansiyeli ve erozyon riski gibi birçok olgu, ilgili yaşam alanının topografik özellikleri ile doğrudan ilişkilidir (Susam ve Oğuz, 2006). Coğrafi Bilgi Sistemleri (CBS), topoğrafik özelliklerin sayısal olarak ortaya çıkarılması yönünde önemli olanaklar sunmaktadır. Özellikle mühendislik çalışmalarında arazi topografyasının ne kadar önemli olduğu dikkate alınırsa CBS'nin sunduğu bu olanakların önemi daha da iyi anlaş1lır. $\mathrm{Bu}$ sebepledir ki son yillarda bu anlamda yapılan bilimsel çalışmalara çok sık rastlanmaktadır (Susam ve Çakar, 2002). Susam ve Oğuz (2006), Tokat ili idari sınırları kapsamında coğrafi bilgi sistemi ortamında yaptıkları bir çalışmada, Tokat ili eğim, bakı ve yükseklik durumunu incelemişler ve Tokat ili arazilerinin eğim, bakı ve yükseklik yüzdeleri yüzölçümü değerlerine göre hesaplayarak grafikler elde etmişlerdir. Elde ettikleri eğim değeri miktarlarına göre Tokat ili arazilerinin büyük çoğunluğunun tarım için uygun olan (\% 0-12) aralıkta olmadığını tespit etmişlerdir. Bakı durumu tespiti sonunda ise arazilerin ana yönlere göre yaklaş1k eşit oranda (kuzey $26.5 \%$, güney $25.6 \%$, doğu 20 $\%$ ve batı $22.2 \%$ dağıldıklarını belirlemişlerdir. Tespit ettikleri bu topoğrafik niteliklere göre Tokat ili arazilerinin çok az bir kısmının topoğrafik açıdan tarımsal kullanıma uygun olduğunu görmüşlerdir.

Tarımda bitki deseni tahmini, rekolte tahmini, çayır ve mera alanlarının belirlenmesi, nadasa bırakılan alanların belirlenmesi, bitki gelişiminin izlenmesi, toprak tasnifi, sulama ve drenaj etütleri, su kaynaklarını koruma planlaması, tarım ve hayvancılığa ilişkin kaynak tahminleri, kırsal yerleşim yerlerinin belirlenmesi gibi birçok tarımsal amaç için CBS kullanılabilmektedir. CBS tarımsal alanların uydu görüntüleriyle tespit edilerek tarımsal iyileştirme, bitki örtüsünün hastalıklı bölgelerini tespit etme ve zirai vergilendirme konularında da etkili olmaktadır. Ekim alanlarının izinsiz kullanılması gibi durumlarda Uzaktan Algılama yöntemi ile elde edilen uydu görüntüleriyle kolaylıkla zirai denetim yapılabilmektedir. Ayrıca uydu görüntüleri sayesinde tarım tipine bağlı olarak çiftçilerin ödeyecekleri vergiler doğrudan hesaplanarak mükelleften otomatik olarak verginin tahsili sağlanabilir (Yomralığlu, 2000).

Geleneksel yöntemlerle zahmetli ve uzun sürede gerektiren bu tür çalışmalar CBS yardımıyla hızlı ve güvenilir düzeyi çok daha yüksek bir performansla kısa bir sürede yapılabilmektedir. CBS teknolojilerinin son yıllarda etkin olarak kullanılması araştırma sonuçlarının hızlı ve güvenilir bir şekilde ortaya konulmasina yardımcı olmaktadır. Özellikle tarımsal çalışmalarda bu teknolojilerden faydalanılması ve bilhassa tarımsal gidișata yön veren kurumlarda CBS birimlerinin oluşturulması bu tekniklerin kullanımını yapılacak çalışmalarda ön plana çıkarmaktadır. Klasik yöntemlerle yapılan arazi çalışmaları özellikle zaman ve veriye ulaşmada birçok zorluklar sunmaktadır.

Alternatif üretim alanlarının belirlenmesi ve tarımsal sürdürülebilirliğin devam etmesi açısından ürün çeşitliliğinin arttırılmasına yönelik yapılacak arazi çalışmalarında CBS teknolojilerinin kullanımının sağlanması son derece önemlidir. CBS tabanlı tekniklerinden faydalanılarak bölgede alternatif ürün olan ceviz yetiştiriciliğine uygun alanların ortaya konulması ile bu çalışmanın bölgede örnek olarak farklı alanlardaki tarımsal potansiyelin öne çıkarılmasına da öncülük edeceği kaçınılmaz olacaktır. Alternatif üretim olarak yetiştiriciliğinin yapılması uygun olan ceviz, ekonomik kazanç olarak getirisi yüksek ürünler arasında yer almaktadır. Tekirdağ ilinin diğer ilçelerine bakıldığında özellikle Merkez ilçe sınırlarında ceviz yetiştiriciliğinin daha fazla olduğu ve bu eğilimin giderek arttığ 1 gözlemlenmiştir. Araştırma sonucunda ortaya konulan veriler 1şı̆̆ında merkez köylerde eğim ve bakı özellikleri dikkate alınarak alternatif tarımsal üretimden biri olan ve bölgede yetiştiriciliği çok az düzeyde 
görülen ceviz alanlarının belirlenmesi ve geliştirilmesinin ortaya konulması amaçlanmıştır.

\section{Materyal ve Metot}

Tekirdağ ili merkez ilçe sınırları $1111 \mathrm{~km}^{2}$ sahip olup, merkez ilçeye bağlı toplamda 55 köy bulunmaktadır. Bu illerde hâli hazırda tarımsal üretim devam etmektedir. Bölgede tarımsal açıdan toplam tarımsal üretimin \%46'nı buğday ve \%36.6'nı ise ayçiçeği ağırlıklı ürün yetiştiriciliği oluşturmaktadır. İl geneline bakıldığında meyvecilik tarımının yapıldığı alan toplam tarımsal üretim alanının $\% 0.46$ 'nı teşkil etmektedir. İl merkezindeki ceviz yetiştiriciliği yapılan alan toplamı 2657 da olup, ceviz meyvesi veren ağaç sayısı ise 13.084 adettir. Üretim kapasitesi 2003 yılında 357.5 ton/y1l olan cevizin 2011 y1lında üretimi 1376.47 ton/yıl'a yükselmiştir (Anonim, 2011). Şekil 1'de Türkiye haritası üzerinde Tekirdağ ilinin konumu verilmekte ve araştırma kapsamında değerlendirilen merkez ilçe sınırları görülmektedir.

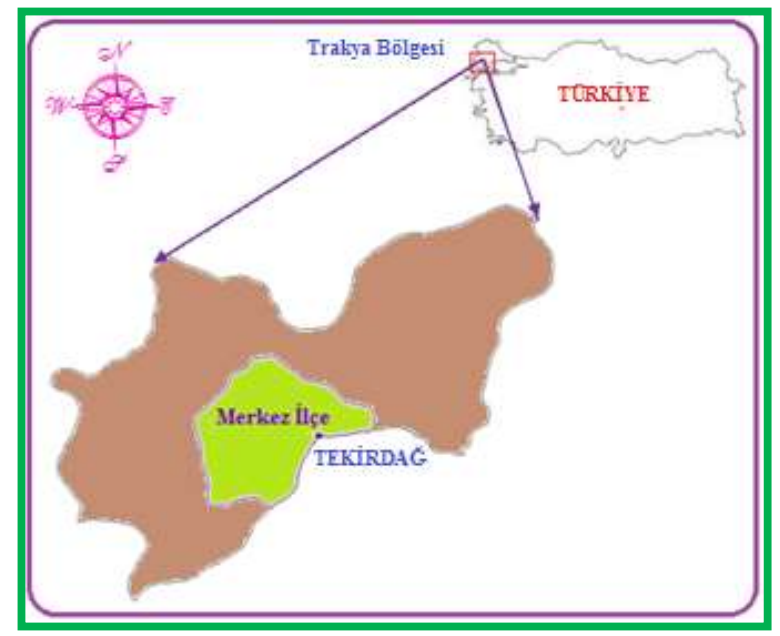

Şekil 1. Araştırma alanının yeri ve konumu.

Uzun yıllık veriler doğrultusunda genel olarak Tekirdağ ili merkez ilçenin yıllık ortalama sicaklık bakımından 13.0 - $14.6{ }^{\circ} \mathrm{C}$, yıllık ortalama bağıl nem $\% 70-78$, yillık toplam buharlaşma miktarı 700-1100 $\mathrm{mm}$ arasında değişmektedir. Rüzgârlar çoğunlukla kuzeyden (poyraz) esmektedir. İlk don Kasım ayının ilk haftasında, son don ise Mart ayının son haftasında görülmektedir (Anonim 2012). Tablo 1'de Tekirdağ merkez ilçede gözlenen uzun yıllara ait ortalama bazı iklim verileri görülmektedir.

Tekirdağ ili topraklarını genel olarak kireçsiz, kahverengi orman ve vertisol topraklar oluşturmaktadır. Kireçsiz kahverengi orman toprakları $\mathrm{ABC}$ profilli topraklardır. $\mathrm{Bu}$ topraklar havzanın üst kısmında yer almaktadır. Eğimleri orta ve dik olup, nadassız kuru tarım yapılan üçüncü sınıf arazilerdir. Vertisoller ise $\mathrm{AC}$ profilli ağır bünyeli topraklar olup, havzanın alt kısımlarında yer almaktadır. Eğimleri düze yakın ve orta derin topraklardır. Tamamı nadassiz kuru tarım yapilan ikinci sinıf arazilerdir Havza toprakları kumlu-killi-tın (SCL) bünyeli, geçirgen, nötr reaksiyonlu, tuzsuz, organik madde içeriği düşük, fosforca orta, potasyumca zengin ve kireçsizdir. Bor, tuzluluk, sodyumluluk ve drenaj sorunları yoktur. Topraklarının çok büyük bir kısmı kireçsiz kahverengi olmak üzere, çok az bir kısmı alüvyal büyük toprak gruplarından meydana gelmiştir (Anonim, 2011). Bunlar geniş düzlükler ve alçak tepelerden oluşan dalgalı bir topografyanın yer aldığı, hafif eğimli ve derin topraklardır. Büyük toprak gruplarının il bazında dağılımı Şekil 2'de verilen harita üzerinde detaylı olarak görülmektedir.

Tekirdağ, Türkiye yüzölçümünün \%0.8'ni, Marmara Bölgesinin \%8.6'n1, Trakya Bölgesinin ise \%26.25'ni oluşturan toplam 621.788 ha'llk alana sahiptir.

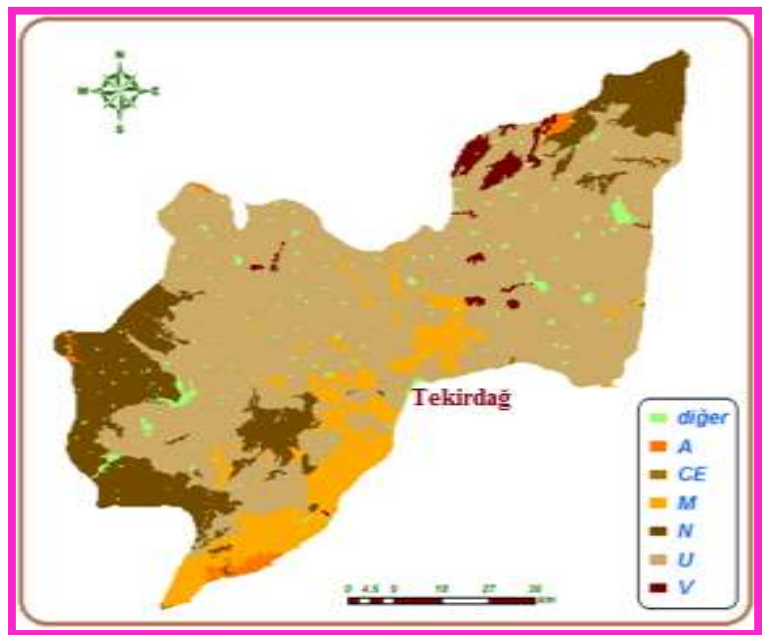

Şekil 2. Tekirdağ ili büyük toprak gruplarının dağılımı. 
Tablo 1. Tekirdağ merkez ilçe uzun yıllar ortalama bazı iklim verileri*.

\begin{tabular}{|c|c|c|c|c|c|}
\hline Aylar & $\begin{array}{c}\text { Ort. Sicaklık } \\
\left({ }^{\circ} \mathrm{C}\right)\end{array}$ & $\begin{array}{l}\text { Toplam Yă̆ğş } \\
(\mathrm{mm})\end{array}$ & $\begin{array}{c}\text { Ort. Rüzgâr Hızı } \\
(\mathrm{m} / \mathrm{s})\end{array}$ & $\begin{array}{c}\text { Ort. Bağıl Nem } \\
(\%)\end{array}$ & $\begin{array}{c}\text { Toplam Buharlaşma } \\
(\mathrm{mm})\end{array}$ \\
\hline Ocak & 4.9 & 65.0 & 3.0 & 82.6 & - \\
\hline Şubat & 5.0 & 51.8 & 3.1 & 80.6 & - \\
\hline Mart & 7.3 & 54.0 & 2.8 & 80.5 & - \\
\hline Nisan & 11.8 & 45.5 & 2.3 & 78.5 & 62.4 \\
\hline Mayıs & 16.6 & 39.9 & 2.2 & 77.1 & 112.4 \\
\hline Haziran & 21.2 & 37.5 & 2.6 & 73.7 & 138.1 \\
\hline теттив. & 23.6 & 26.6 & 2.7 & 70.9 & 176.8 \\
\hline Ă̆ustos & 23.4 & 20.2 & 2.6 & 72.0 & 170.2 \\
\hline Eylül & 19.9 & 35.6 & 2.7 & 75.0 & 113.2 \\
\hline Ekim & 15.3 & 57.1 & 2.7 & 78.9 & 67.8 \\
\hline Kasım & 10.4 & 73.3 & 3.1 & 81.9 & 22.6 \\
\hline Araltk & 6.8 & 78.6 & 2.7 & 82.6 & 9.2 \\
\hline Yıllık & 13.9 & 585.1 & 2.7 & 77.9 & 872.7 \\
\hline
\end{tabular}

* Kaynak: Anonim (2012a).

Toprakları, geniş düzlükler ve alçak tepelerden oluşmuştur. İl topraklarının 468.865 ha $(\% 75,41)$ gibi büyük bir bölümü işlemeli tarıma elverişli topraklardan oluşmaktadır. $\mathrm{Bu}$ toprakların 428.081 hektarında nadassız kuru tarım, 34.900 hektarında sulu tarım ve geri kalanında ise bağ-bahçe tarımı yapılmaktadır. Sulu tarım yapılan 34900 ha arazinin \%83.99'u düz ve düze yakın, \%13.76'sı hafif, \%1.59'u orta, $\% 0.66$ 's1 dik eğimlidir. $\mathrm{Bu}$ arazilerin topraklarının \%93.39'u derin, \%5.46'1 orta derin ve \%1.15'i sı̆ğdır. İlin 105.606 hektarı (\%16.98) orman-fundalik ve 31.711 hektar1 (\%5.10) çayır-mera alanlarıyla kaplıdır (Anonim, 2011).

Çalışmada 1/25.000 ölçekli topografik sayısal haritalar yardımıyla Arc GIS 10.1 yazılımının spatial modülünün "aspect" uygulaması kullanılarak 8 farklı yön ve düz alanlardan oluşan bakı haritaları oluşturulmuştur (Wilson vd., 2000). Havza ve alt havza gruplarına ilişkin üretilen farklı yönler, daha genel olarak değerlendirmek amaciyla tüm ara yönler ana yöne eklenmiş ve değerlendirme doğu, bat1, kuzey, güney ve düz yönler olacak şekilde 5 farklı kategoride yapılmıştır. Merkez ilçe sınırlarını kapsayan sayısal paftaların CBS ortamında birleştirilmesi sonucunda spatial modülünün slope analizi ile eğim dağılımları ortaya konulmuştur. Çalışma alanının toprak özelliklerinin belirlenmesi işlemlerinde ise 1/25.000 ölçekli sayısal toprak haritaları kullanılmıştır (Anonim, 1980). Sayısal toprak haritalarının Arc GIS 10.1 yazılımı yardımıyla katmansal olarak sinıflandırılması yapılarak toprak derinlik haritası (DER), arazi kullanım kabiliyet sınıfları (AKK) ve büyük toprak grupları (BTG) sınıflandırılmıştır.

Bu çalışma kapsamında özellikle sayısal altlık haritalar kullanılmıştır. Topografik haritalar 1/25.000 ölçekli olup, sayısal ortamda Arc GIS 10.1 yazılımı kullanılarak gerekli pafta birleştirmeleri yapılmış ve sürekli yüzeyler halinde tesviye eğrileri birleştirilmiştir. Çalışmada 14 adet sayısal topografik pafta kullanılmıştır. Araştırmada ceviz yetiştiriciliğine uygun alanların tespiti için bazı kriterler dikkate alınarak ilgili sayısal haritaların çakıştırılması sonucunda uygun ceviz alanları belirlenmiştir. $\mathrm{Bu}$ bağlamda ceviz yetiştiriciliğine uygun alanların belirlenmesinde Akça ve Ferhatoğlu (2001)'de verilen esaslar dikkate alınmıştır. Ceviz yetiştiriciliği için CBS ortamında mekânsal çakıştırmalarda kullanılan kriterler Tablo 2'de özet halde sunulmuştur.

Ceviz ağaçları toprak bakımından seçici olmamakla beraber, taban suyu seviyesi 2.53.0 metreden yukarı olmayan, fazla su tutmayan, gevşek, süzek, çakıll1-alüvyonlu topraklarda daha iyi gelişir. Su tutan killi topraklarda ve durgun sulu yerlerde gelişemez. Ceviz ağacının kökleri kazık köklü olup, derine uzadıklarından alt kısımları rutubetli olan, derin ve yumuşak topraklar yetiştiricilik için daha uygundur. Fazla oranda kireç ihtiva etmeyen ve su tutmayan, 
nemliliğini muhafaza eden derin topraklarda

iyi gelişmektedir (Ferhatoğlu, 2001).

Tablo 2. Ceviz yetiştiriciliğine uygun alanların belirlenmesinde kullanılan kriterler.

\begin{tabular}{|c|c|c|c|c|c|c|}
\hline $\begin{array}{l}\text { Taban suyu } \\
\text { Seviyesi }\end{array}$ & $\begin{array}{l}\text { Toprak } \\
\text { Tekstürü }\end{array}$ & Toprak grubu & $\begin{array}{l}\text { Toprak } \\
\text { verimliliğ } i\end{array}$ & $\begin{array}{l}\text { Topografik } \\
\text { Ĕ̈im }\end{array}$ & $\begin{array}{l}\text { Toprak } \\
\text { derinliği }\end{array}$ & $\begin{array}{l}\text { Yöney } \\
\text { (Bakı) }\end{array}$ \\
\hline $2.5-3 \mathrm{~m}$ & $\begin{array}{l}\text { Kumlu, } \\
\text { Tinl1, Siltli, } \\
\text { Kumlu-Tinlı }\end{array}$ & $\begin{array}{l}\text { BTG: A, CE, M, N, U } \\
\text { AKK: I-IV. sinıf arazi }\end{array}$ & $\begin{array}{l}\text { Kireç } \\
\text { içermeyen, } \\
\text { organik } \\
\text { maddece zengin }\end{array}$ & $\% 3-10$ & En az $2 \mathrm{~m}$ & $\begin{array}{l}\text { Güney, } \\
\text { Güneybatı, } \\
\text { Güneydoğu }\end{array}$ \\
\hline
\end{tabular}

Elde edilen harita çıktıları dahilinde bak1 haritası kullanılarak güney, güneybatı, güneydoğu alanları ile eğim grupları \%3'den büyük olan alanlar, alüvyal topraklar (A), kestane rengi topraklar (CE), kahverengi orman toprakları $(\mathrm{M})$, kireçsiz kahverengi orman toprakları $(\mathrm{N})$, kireçsiz kahverengi topraklar (U), Vertisoller (V), Toprak derinliği 2 m'den fazla olan alanlar arazi kullanım kabiliyetleri de dikkate alınarak CBS ortamında üst üste çakıştırılmıştır. Genel anlamda çeşit belirtilmeksizin ceviz yetiştiriciliği için en uygun alanların belirlenmesinde Şekil 3'de verilen şematize yaklaşım kullanılmıştır.

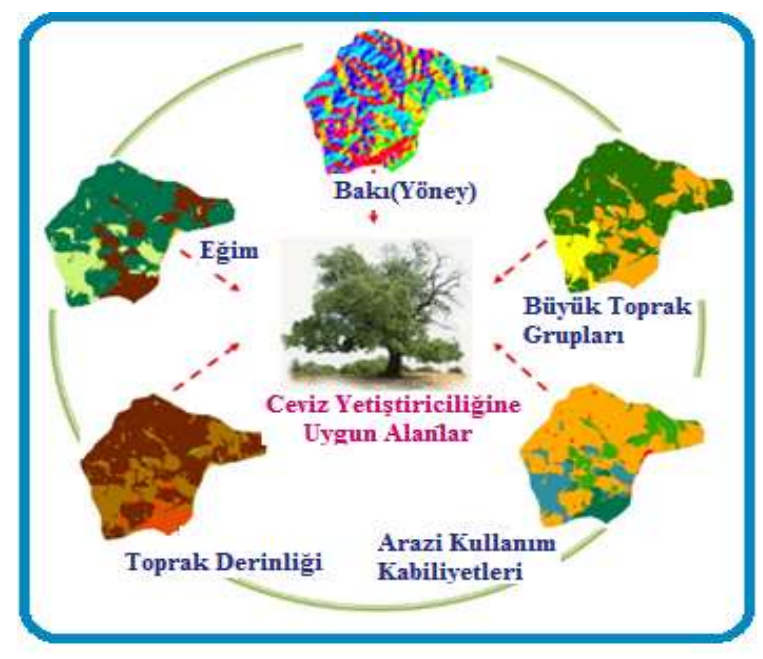

Şekil 3. Ceviz yetiştiriciliğine uygun alanların belirlenmesine ilişkin şematize yaklaşım

\section{Araştırma Bulguları}

\subsection{Büyük Toprak Gruplart}

Araştırma kapsamındaki Tekirdağ ili merkez ilçe sınırlarının büyük toprak gruplarının dağılımı sınıflandırılarak harita çıktısı Şekil 4'de, alansal dağılımları ise Tablo 3'de verilmiştir. $\mathrm{Bu}$ bağlamda sınıflandırılmış büyük toprak grupları 7 kategoride gruplandırılmıştır. Bunlar alüvyal topraklar (A), kestane rengi topraklar (CE), kahverengi orman toprakları (M), kireçsiz kahverengi orman toprakları $(\mathrm{N})$, kireçsiz kahverengi topraklar (U), Vertisol (V) ve diğer toprak gruplarıdır. Sınıflandırma sonucunda özellikle $\mathrm{U}, \mathrm{M}$ ve $\mathrm{N}$ büyük toprak gruplarının bölgede hakim olduğu görülmektedir. Ceviz yetiştiriciliği bakımından değerlendirildiğinde büyük toprak grupları bakımından kıyı kesimi hariç tüm alanların ceviz yetiştiriciliğine uygun olduğu söylenebilir.

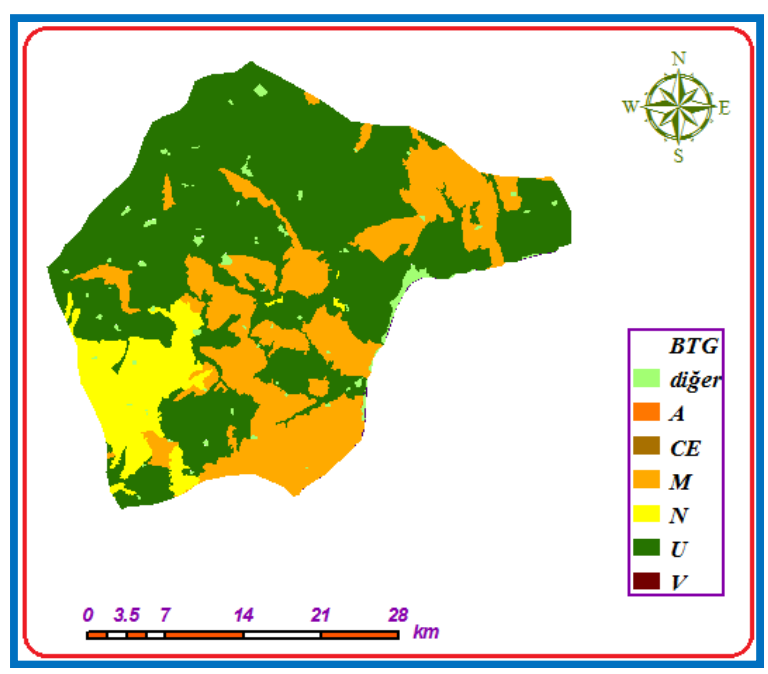

Şekil 4. Tekirdağ ili Merkez ilçenin büyük toprak gruplarının dağılımı

Merkez ilçe sınırlarında toprakların alansal dağılımına bakıldığında en fazla 41.082 ha alanda kireçsiz kahverengi toprakların (U) hakim olduğu, 256 ha alanda ise Kestane rengi toprakların (CE) en az yayılım ile dağılım gösterdiği görülmektedir (Tablo 3 ). Merkez ilçede 101.402 ha alanın BTG 
bakımından ceviz yetiştiriciliğine uygun olduğu söylenebilir.

Tablo 3. Tekirdağ ili Merkez ilçenin büyük toprak gruplarının alansal dağılımı

\begin{tabular}{|c|c|}
\hline $\begin{array}{c}\text { Büyük Toprak Gruplart } \\
(\text { BTG })\end{array}$ & Alan (ha) \\
\hline A & 314 \\
\hline CE & 256 \\
\hline M & 38.400 \\
\hline N & 21.350 \\
\hline U & 41.082 \\
\hline V & 8.833 \\
\hline diğer & 865 \\
\hline
\end{tabular}

\subsection{Toprak Derinlikleri}

Toprak derinliklerine göre sinıflandırma sonucunda merkez ilçedeki arazilerin dağılım durumu Şekil 5'de verilen harita üzerinde görülmektedir.

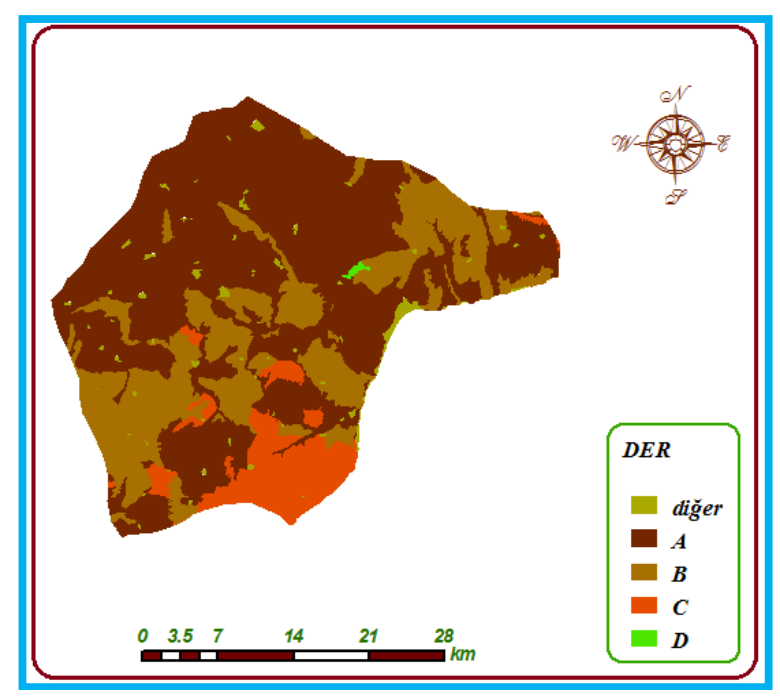

Şekil 5. Toprak derinliklerinin dağılımı.

Toprak derinliği bakımından beş sınıfta kategorize edilen araştırma alanında, en çok A ve B profil derinliklerini içeren topraklar bulunurken Tekirdağ il merkezinin güney kısmına doğru ise toprakların $\mathrm{C}$ profil derinliğini içerdiği görülmektedir. Tablo 4'de Tekirdağ ili merkez ilçe sınırlarındaki toprakların derinlik sınıflarına ilişkin alansal dağılımlar verilmiştir.
Tablo 4. Toprak derinlik sinıflarının alansal dağılımları

\begin{tabular}{|c|c|}
\hline $\begin{array}{c}\text { Toprak Derinlik } \\
\text { Gruplart (DER) }\end{array}$ & Alan (ha) \\
\hline A & 66.154 \\
\hline B & 26.171 \\
\hline C & 16.915 \\
\hline D & 150 \\
\hline diğer & 1.710 \\
\hline
\end{tabular}

Toprak derinlik grupları bakımından Tekirdağ ili merkez ilçe sınırlarında en fazla derinlik sinıfinı 66.154 ha ile A sinıfi topraklar oluştururken, en az alansal dağılıma sahip toprak derinlik sınıfinı ise 150 ha ile D grubu topraklar oluşturmuştur (Tablo 4). Toprak derinliği bakımından 18.775 ha alan Ceviz yetiştiriciliğine uygun olduğu söylenebilir.

\section{3. Ĕ̈im Dağılımları}

Araştırmada merkez ilçe arazi sınırları dahilinde topoğrafik olarak arazinin eğim dağılımı belirlenmiştir. Altı kategoride sinıflandırma sonucu ortaya konulan eğim dağılımları Şekil 6'da, eğim gruplarının alansal dağılımları ise Tablo 5 'de verilmiştir.

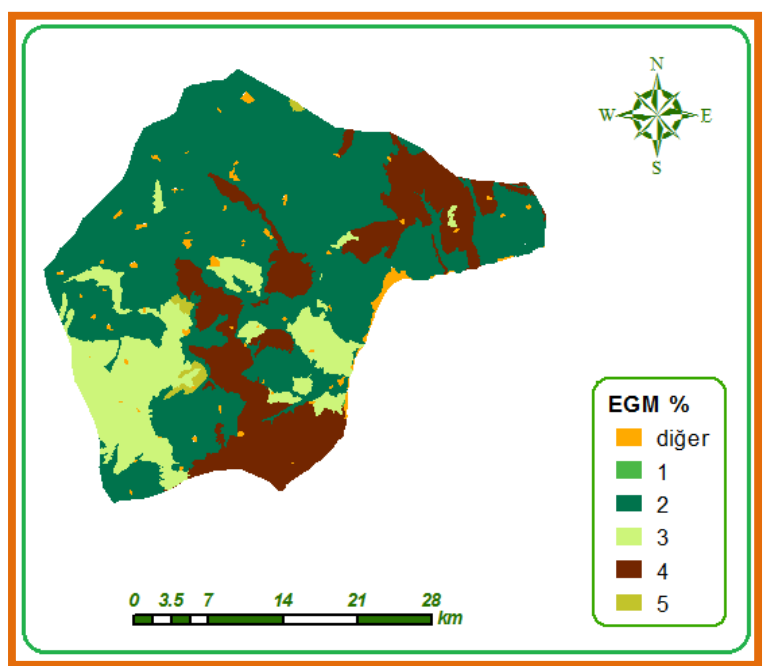

Şekil 6. Tekirdağ ili merkez ilçe sınırlarındaki arazi eğim dağılımı

Eğim dağılımlarına bakıldığında merkez ilçe toprakları altı eğim grubunda sınıflandırılmıştır. 
En fazla toprak alanı 24.934 ha alanla \% 2'lik toprak eğim grubunda yer alırken, en az eğim grubu ise 10.3 ha alanla \%1'lik toprak eğim grubunda yer almıştır. Merkez ilçede 38.258 ha alan Eğim bakımından Ceviz yetiştiriciliğine uygun olarak söylenebilir.

Tablo 5. Eğim dağılımının alansal değişimi

\begin{tabular}{|c|c|}
\hline Ĕ̈im (\%) & Alan (ha) \\
\hline 1 & 10.3 \\
\hline 2 & 24.934 \\
\hline 3 & 8.113 \\
\hline 4 & 5.211 \\
\hline 5 & 834.6 \\
\hline Diğer & 36.005 \\
\hline
\end{tabular}

\subsection{Arazi Kullanım Kabiliyet Sınıfları}

Çalışma kapsamında araştırma alanının arazi kullanım kabiliyet sinıfları analiz edilerek Şekil 7'de verilmiştir.

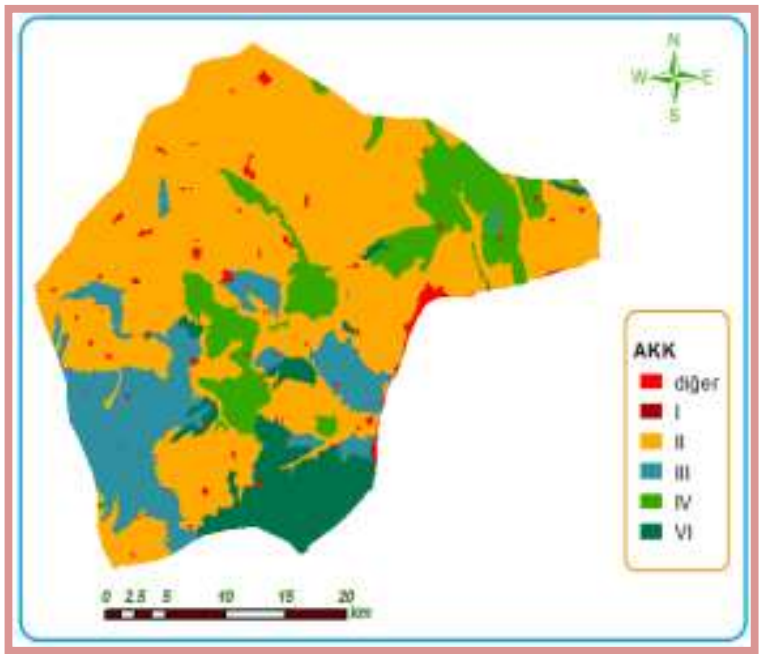

Şekil 7. Arazi kullanım kabiliyet sınıflarının dağılımı (AKK)

Arazi kullanım kabiliyet sinıfları altı kategoride sınıflandırılan çalışma alanının ağırlıklı olarak II, III, IV ve VI sinıf arazi özelliklerine sahip olduğu görülmektedir. $\mathrm{Bu}$ bağlamda özellikle I-IV. sınıf tarım arazileri toprak işlemeli tarıma uygun alanlar olarak nitelendirilebilir. Özellikle güney kısımda yer alan koyu yeşil skala ile ifade edilen alan VI. sınıf tarım alanı olduğu için toprak işlemeli tarıma uygun bir alan değildir. Buradan hareketle Tekirdağ ili merkez ilçe alanlarının tamamına yakınının ceviz yetiştiriciliğine uygun olabileceği söylenebilir (Şekil 7). Arazi kullanım kabiliyet sınıflarının alansal dağılımları ise Tablo 6'da hesaplanarak sunulmuştur.

Tablo 6. Arazi kullanım kabiliyet sınıflarının alansal dağılımları

\begin{tabular}{|c|c|}
\hline $\begin{array}{c}\text { Arazi Kullanım Kabiliyet } \\
\text { Sinıfları (AKK) }\end{array}$ & Alan (ha) \\
\hline I & 221 \\
\hline II & 61.009 \\
\hline III & 17.100 \\
\hline IV & 14.023 \\
\hline VI & 18.300 \\
\hline diğer & 447 \\
\hline
\end{tabular}

Arazi kullanım kabiliyet sınıflarının Tekirdağ ili merkez ilçe sınırları dâhilindeki dağılımlarına bakıldığında, en fazla alansal dağılımın 61.009 ha ile II. sınıf tarım arazisi, en az alansal dağılımın ise 221 ha ile I. sınıf tarım arazisi olduğu görülmektedir. Ceviz yetiştiriciliği için uygun alanların I-IV. sınıf arasındaki tarımsal alanlar olduğu dikkate alındığında 92.353 ha alanın AKK açısından uygun olduğu söylenebilir (Tablo 6).

\subsection{Bakı (Yöney) Dağılımları}

Araştırma alanının yöney durumlarını değerlendirmek amaciyla elde edilen bak1 (yöney) haritası Şekil 8'de verilmiştir. Bak1 haritasında yöney bakımından araştırma alanının özellikle sahil kesimlerinde güney yamaçlı konumda iken, üst kısımlara doğru dağılımın kuzey ve batı yönünde bir konum arz ettiği görülmektedir (Şekil 8).

\subsection{Topografik Yükselti Dă̆ılımları}

Tekirdağ ili merkez ilçe sınırlarını kapsayan alanın sayısal 1/25.000 ölçekli haritalar yardımıyla oluşturulmuş sayısal yüksek modeline ilişkin çıktı haritası Şekil 9'da verilmiştir. 


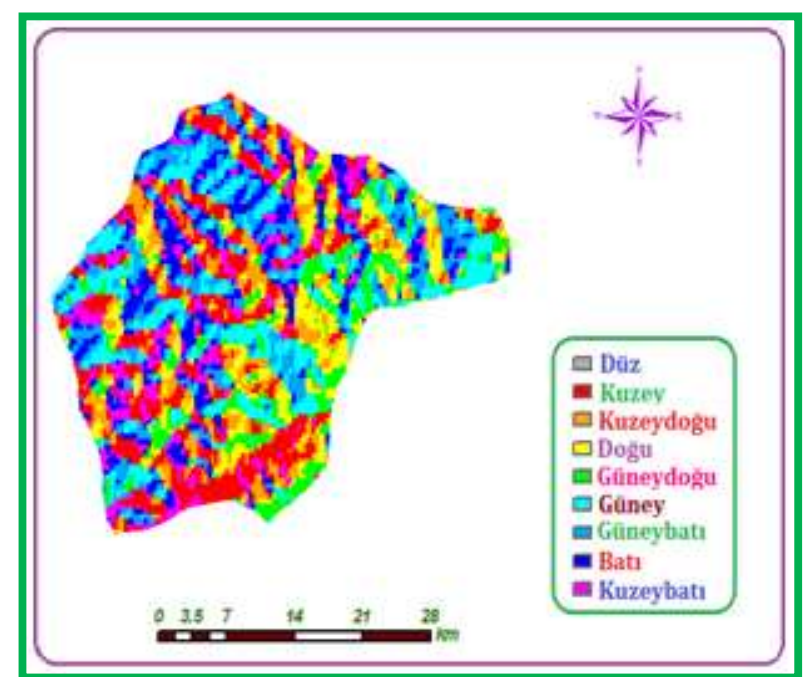

Şekil 8. Bakı (yöney) haritası

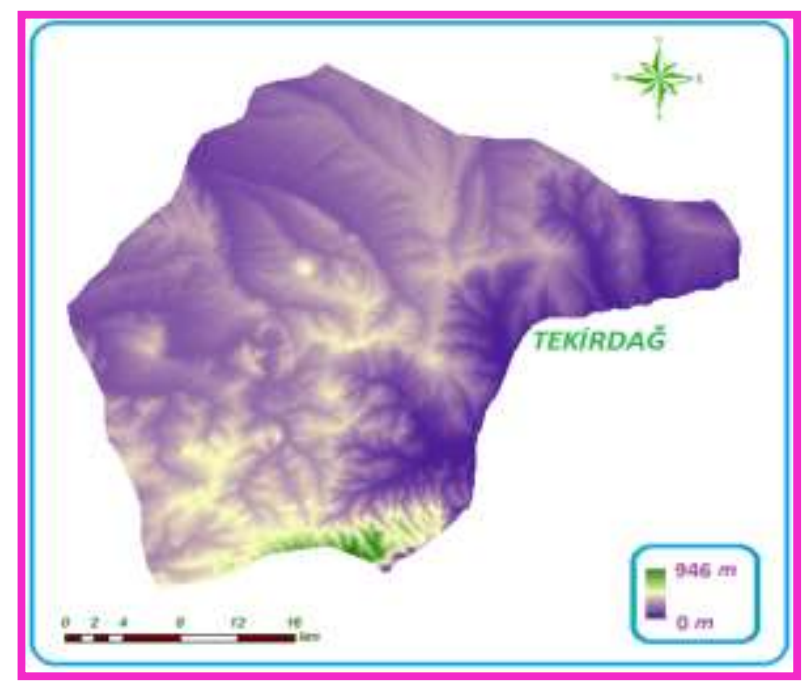

Şekil 9. Tekirdağ ili merkez ilçe arazisinin sayısal yükseklik modeli

Alanın sayısal topografik yüksekliği 0-946 m arası değişim göstermektedir. İlgili alan sahil şeridinde olduğu için $0 \mathrm{~m}$ ile gösterilen alanların özellikle sahil şeridini temsil ettiği açıçca bellidir. Ancak 943 m ile en yüksek alan ise Tekirdağ ili merkezinin güneybatısındaki Uçmak Dere mevkii olarak belirlenmiştir. Topoğrafik yükselti olarak Tekirdağ ili merkezi özellikle sahil ve kıyı şeritten uzaklaştıkça hızlı bir şekilde yükselen topografik dağılımlara sahiptir. Bu topografik yükseltiler tarımsal gidişata engel teşkil etmemektedir. Kıyıdan uzaklaştıkça yer yer düzlük ve tarıma müsait alanların olduğu da görülmektedir (Şekil 9).

\subsection{Ceviz Yetişstiriciliğine Uygun Alanlar}

Ceviz yetiştiriciliği özellikle Tekirdağ ilinde son zamanlarda alternatif tarımsal üretim şekli olarak yayılım göstermeye başlamıştır. Merkez ilçedeki tarımsal alanlarda ceviz yetiştiriciliğine uygun alanların tespit edilmesi zaruri ihtiyaç haline gelmiştir. CBS ortamında çakıştırılmış haritalar neticesinde elde edilen ceviz yetiştiriciliğine uygun alanlar Şekil $10^{\prime}$ da verilmiştir. Tekirdağ ili merkez ilçe sınırlarındaki ceviz yetiştiriciliğine uygun alanların toplamı 11.140 ha olarak belirlenmiştir (Şekil 10).

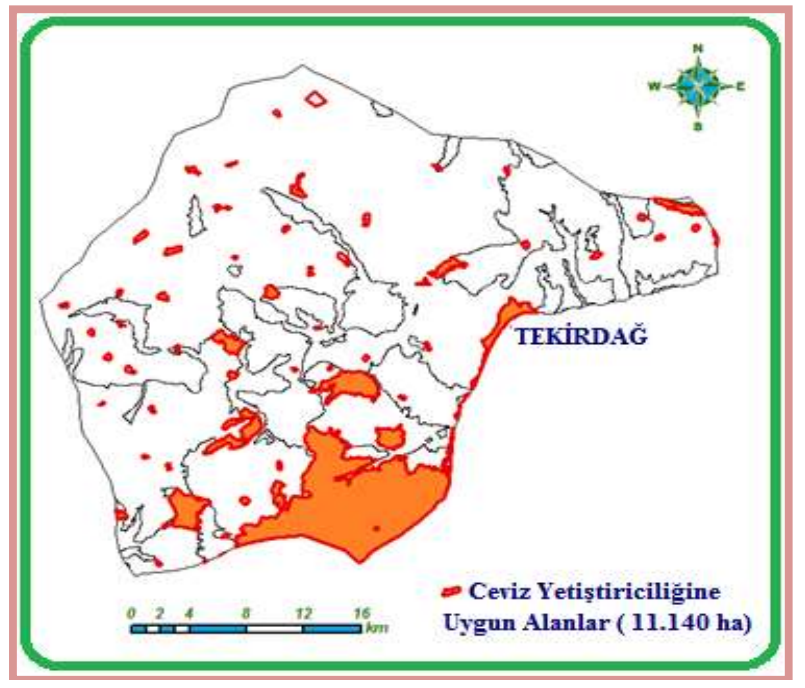

Şekil 10. Ceviz yetiştiriciliğine uygun alanlar

\section{Tartışma ve Sonuçlar}

Ceviz yetiştiriciliği için tavsiye edilen toprak; orta tekstürlü, Kumlu, Tinlı, Siltli ve kumlutınlı topraklardır. Ceviz yetiştiriciliği için toprak derinliğinin en az 150-160 cm arasında olması tavsiye edilir. Ancak Kaliforniya'da ve özellikle J.hindsü ve Paradox Ceviz anaçları için minimum 150-190 cm veya daha fazla kesiksiz toprak derinliği tavsiye edilmektedir. Ülkemiz ceviz yetiştiriciliğinde ise anaç olarak J.regia anaçları üzerine aşılı ceviz ağaçları için kesintisiz 270-300 cm derinlikte bir toprak arzulanır (Akça, 2001). Çelik vd., (1998)'de yapmış oldukları başka bir çalışmada ürün çeşidi ve yetiştiriciliğin topoğrafik eğim durumuna göre değişkenlik gösterdiğini, bağların kurulduğu arazinin eğiminin iklim yönünden büyük önem taşıdığını, 1lıman iklim bölgelerinde arazinin 
eğiminin \%5-10, soğuk bölgelerde güneye bakan yerde eğimin \%10-15 olmasının bağcılık için uygun olabileceğini bildirmişlerdir. Bağ alanlarında olduğu gibi ceviz alanlarının belirlenmesinde de eğim durumu önemli bir etkendir. Eğimin fazla olduğu veya düze yakın alanlarda ceviz yetiştiriciliğinin yapılması tercih edilemeyecek kıstaslar arasında yer almaktadır. $\mathrm{Bu}$ sebeple, eğimi \%3-10 arasındaki alanların ceviz yetiştiriciliği bakımından uygun olabileceği yapılan çalışmalar ile desteklenmiştir.

Goudie (2004), yaptığı bir çalışmada bakı durumunun topoğrafik özellikle değişim göstermekle birlikte özellikle bitki gelişimi ve kar türü yağışların erime ve taşkına geçmesinde büyük rol oynadığını, kuzeye bakan yamaçlarda kar erimelerinin yavaş ve bitki gelişim durumunda diğer yamaçlara oranla az ve suyu tutan etmenlerin zayif olduğunu saptamıştır. Bu durumda tarımsal ürün deseninin belirlenmesinde bak1 durumunun tespiti ve yetiştiriciliğin bak1 durumlarına göre farklılık gösterebileceği kaçınılmazdır. Ceviz yetiştiriciliğine uygun alanların tespit edilmesinde de bakı durumu göz önünde bulundurulmalı ve uygun yöney belirlendikten sonra ceviz yetiştiriciliğinin yapılmalıdır. Ceviz eylem planı dahilinde Türkiye genelinde özel ağaçlandırma sahaları mevcuttur. Özellikle özel ağaçlandırma sahaları kapsamında bu ürünün yetiştirilmesi ile birlikte yetiştiricilere tarımsal teşviklerle birlikte önemli katkılar sağlayacaktır (Anonim, 2012b).

Çalışma kapsamında cevizin toprak ve topoğrafik istekleri göz önüne alınarak gerekli sayısal haritalar CBS ortaminda analize tabi tutulmuş ve ceviz yetiştiriciliğine uygun alanlar tespit edilmiştir. Bu anlamda Tekirdağ ili merkez ilçe sınırlarında ceviz yetiştiriciliğine AKK bakımında 93.353 ha, eğim bakımından 38.258 ha, toprak derinliği açısından 18.775 ha, BTG olarak 101.402 ha alanın uygun olduğu söylenebilir. Araştırma sonucunda bölgede alternatif tarım şekli olarak tercih edilebilecek ve ekonomik değeri yüksek olan cevizin merkez ilçeye bağlı 55 köyde ve toplam 11.140 ha alanda yetiştirilebileceği ortaya konulmuştur. Sonuç olarak, Tekirdağ ilinin tamamında ceviz yetiştiriciliğine uygun tüm köyler bu kapsamda değerlendirilebilir.

Yersel ölçmelere ve klasik yöntemlere göre hız, doğruluk, maliyet ve zaman açısından büyük avantaj sağlayan coğrafi bilgi sistem tekniklerinin kullanılması, arazi örtü/arazi kullanım türlerindeki değişimlerin saptanmasında ve güncelleştirilmesinde önemli rol oynamaktadır (Özsoy, 2007). Klasik yöntemlerle yapılan bu tür çalışmalarda farklı verilerin çakıştırılması zor ve elde edilen sonuçlarda hata payı yüksek olmaktadır. Bu nedenle CBS'nin ürün deseni belirleme çalışmalarında aktif olarak kullanılması tarımsal sürdürülebilirlik ve alternatif ürün yetiştiriciliğinin belirlenmesine olumlu katkılar sağlayacaktır.

\section{Teșekkür}

Bu çalışma, TUBİTAK-2209 Projesi kapsamında 2012 yılında desteklenmiştir. Katkılarından dolayı TÜBİTAK-BİDEB Proje Koordinatörlüğüne Teşekkür ederiz.

\section{Kaynaklar}

Akça, Y., 2001. Ceviz Yetiştiriciliği.Arı Ofset Matbaas1, s.62-63, İstanbul.

Anonim, 1980. Sayısal Toprak Haritaları. Mülga Köy Hizmetleri Genel Müdürlüğü, Ankara.

Anonim, 2011. Tekirdağ İli Tarım Raporu. Gıda, Tarım ve Hayvancılık İl Müdürlüğü, Tekirdağ.

Anonim, 2012a. Tekirdağ ili Uzun Y1llık Ortalama İklim Verileri. Tekirdağ Meteoroloji İl Müdürlüğü, Tekirdağ.

Anonim, 2012b. Ceviz Eylem Planı Orman Genel Müdürlüğü, Ankara.

Çelik, H., Ağaoğlu, Y.S., Fidan, Y., Marasalı, B. ve Söylemezoğlu, G., 1998. Genel Bağcılık. s.13-15, Fersa Matbaacılık, Ankara. 
Goudie, A.S., 2004. Encyclopedia of Geomorphology: Volume 1. Routledge Taylor \& Francis Group, London.

Ferhatoğlu, Y., 2001. Ceviz Yetiştiriciliğii. Tarım ve Köy İşleri Bakanlığı, Teşkilatlanma ve Destekleme Genel Müdürlüğü Yayınları, s.4, Ankara.

Özsoy, G., 2007. Uzaktan Algılama (UA) ve Coğrafi Bilgi Sistemi (CBS) Teknikleri Kullanılarak Erozyon Riskinin Belirlenmesi Uludağ Üniv. Fen Bilimleri Enst., Toprak Anabilim Dalı, Doktora Tezi, s.20, Bursa

Susam, T. ve Çakar, S., 2002. The Touristic Map of Tokat province. International Semposium on Geographic Information Systems, İstanbul, Turkey.
Susam, T. ve Oğuz, İ., 2006. CBS İle Tokat İli Arazi Varlığının Eğim ve Bakı Özelliklerinin Tespiti ve Tarımsal Açıdan İrdelenmesi. Gaziosmanpaşa Üniversitesi, Ziraat Fak. Dergisi, 23 (1), 67-74, Tokat.

Wilson, J.P. ve Gallant, J. C., 2000. Terrain Analysis, Principles and Applications, Jhon Wiley\&Sons, Inc. USA.

Yomralığlu, T., 2000. Coğrafi Bilgi Sistemleri Temel Kavramlar ve Uygulamalar. Karadeniz Teknik Üniversitesi, Mühendislik-Mimarlık Fak., Jeodezi ve Fotogrametri Mühendisliği Bölümü, s.479, Trabzon. 